\title{
PENGARUH AROMATERAPI JAHE TERHADAP MUAL MUNTAH PADA PASIEN PASKA OPERASI DENGAN ANESTESI UMUM
}

\author{
Ayu Retno Kinasih*, Efa Trisna*, Siti Fatonah* \\ *Jurusan Keperawatan Poltekkes Tanjungkarang
}

\begin{abstract}
Mual muntah pasca operasi terjadi berkisar 20-30\% dari seluruh pembedahan umum dan lebih kurang 7080\% pada kelompok risiko tinggi di Amerika Serikat. Sedangkan untuk Indonesia, angka kejadian mual muntah pasca operasi belum tercatat dengan jelas. Pada pre survey yang dilakukan di ruang rawat inap bedah wanita, terdapat tujuh pasien pasca operasi dengan anestesi umum, tiga (43\%) diantaranya mengeluh mual muntah. Tujuan penelitian ini adalah untuk mengetahui pengaruh aromaterapi jahe terhadap mual muntah pada pasien pasca operasi dengan anestesi umum di ruang Mawar dan Kutilang RSUD Dr. H. Abdul Moeloek Provinsi Lampung. Metode penelitian yang digunakan adalah Quasi Eksperimen dengan desain Non Equivalent Control Group. Jumlah sampel 16 orang. Analisis data yang digunakan adalah analisis univariat dan analisis bivariat menggunakan uji $t$ - Independent. Hasil penelitian ini didapatkan $\rho<0.05$ yaitu $\rho=0.003$, ini berarti ada perbedaan skor mual muntah pasca operasi pada kelompok kontrol dan intervensi dengan selisih mean 0.88. Saran bagi RSUD Dr. H. Abdul Moeloek Provinsi Lampung diharapkan terapi komplementer aromaterapi jahe dapat diterapkan pada pasien yang mengalami mual muntah pasca operasi, bagi responden diharapkan dapat menggunakan aromaterapi jahe jika terjadi mual muntah dikemudian hari.
\end{abstract}

Kata Kunci: Aromaterapi Jahe, Mual Muntah, Post Operasi

\section{LATAR BELAKANG}

Pembedahan atau operasi adalah
semua tindakan pengobatan yang
menggunakan menggunakan cara invasif dengan membuka atau menampilkan bagian tubuh yang akan ditangani. Pembukaan bagian tubuh ini pula umumnya dilakukan dengan membuat sayatan. Setelah bagian yang akan ditangani tampak, dilakukan tindakan perbaikan yang diakhiri dengan penutupan dan penjahitan luka (Sjamsuhidajat et al, 2010). Pembedahan terdiri dari tiga fase: fase praoperatif, fase intraoperatif, dan fase pascaoperatif (Kozier et al, 2010).

Mual muntah pasca operasi adalam bahasa inggris disebut sebagai Post Operative Nausea and Vomiting (PONV). Mual muntah terjadi dalam waktu 24 jam setelah operasi. Penyebab mual muntah pasca anestesi dianggap multifaktor, karena bisa melibatkan faktor risiko dari individunya, jenis anestesi dan bahkan tindakan pembedahannya (McCracken, Houston, \& Lefebvre, 2008). Sekitar 71 juta orang pasien per tahun di Amerika Serikat menjalani pembedahan. Insiden mual muntah pasca operasi berkisar 20$30 \%$ dari seluruh pembedahan umum dan lebih kurang 70-80\% pada kelompok risiko tinggi (Wijaya et al, 2014). Kejadian mual muntah pasca operasi di Indonesia belum tercatat dengan jelas.

Hasil pre survey peneliti yang dilakukan di ruang rawat inap bedah wanita, terdapat tujuh pasien pasca operasi dengan anestesi umum, tiga (43\%) diantaranya mengeluh mual muntah. Observasi pada salah satu pasien yang mual dan muntah skala 1 (mual menetap kurang dari 10 menit dan atau muntah hanya sekali, tidak membutuhkan pengobatan), terjadi peningkatan denyut nadi, mual muntah terjadi dua jam pasca operasi dan selanjutnya hanya mual tetapi tidak muntah dalam 90 menit berikutnya. Hasil wawancara pada pasien tersebut didapatkan, pasien merasa mual, pasien merasa akan muntah lagi tetapi tidak bisa, kepala pusing, mengantuk, perut begah, mulut kering dan badan terasa lemas.

Berdasarkan dokumentasi dari ruang Post Anesthesia Care Unit (PACU) pasien pasca operasi dengan anestesi umum pada 
bulan Januari 2018 tercatat 48 pasien dari ruang Mawar dan 39 pasien dari ruang Kutilang.

Hasil penelitian yang dilakukan oleh Hosseini \& Adib-Hajbaghery (2015) dengan judul "Ginger Essence Effect on Nausea and Vomiting After Open and Laparoscopic Nephrectomies" didapatkan bahwa penggunaan aromaterapi esensial jahe, efektif dan disarankan sebagai obat komplementer untuk mengurangi mual muntah pada pasien operasi nefrektomi secara terbuka maupun pasien nefrektomi laparoskopi.

\section{METODE}

Jenis penelitian yang digunakan dalam penelitian ini adalah penelitian kuantitatif. Desain penelitian menggunakan Quasi Eksperimen dengan rancangan Non-equivalen Control Group.

Populasi dalam penelitian ini adalah pasien paska operasi dengan anestesi umum dengan jumlah sampel penelitian sebanyak 16 orang yang dibagi menjadi 2 kelompok, 8 orang pada kelompok kontrol dilakukan perlakuan dengan pemberian plasebo dan 8 orang pada kelompok intervensi diberikan perlakuan dengan aromaterapi jahe. Analisis data yang digunakan adalah analisis univariat dan analisis bivariat menggunakan uji $t-$ independent.

\section{HASIL}

Hasil dari penelitian didapatkan jumlah responden terbanyak adalah perempuan dengan persentase $75 \%$, pada kategori umur, sebagian besar lansia akhir (56-65 tahun) dengan persentase $25 \%$. Pada kategori memiliki riwayat mual muntah pasca operasi, sebagian besar dengan persentase $68,75 \%$ memiliki riwayat mual muntah pasca operasi. Pada katagori kebiasaan merokok sebagian besar tidak merokok dengan persentase $68,75 \%$.
Tabel 1: Distribusi Rata-rata Mual Muntah Sebelum dan Sesudah Pemberian Plasebo pada Kelompok Kontrol

\begin{tabular}{lccc}
\hline \multicolumn{1}{c}{ Mual - Muntah } & Mean & Median & SD \\
\hline Sebelum & 2.25 & 2 & 0.518 \\
\hline Sesudah & 1.50 & 1.5 & 0.707 \\
\hline
\end{tabular}

Berdasarkan tabel di atas menunjukan bahwa hasil pretest mual muntah pasca operasi pada kelompok kontrol didapatkan hasil mean 2.25, median 2, standar deviasi 0.518, Sedangkan hasil posttest mual muntah pasca operasi pada kelompok kontrol didapatkan hasil mean 1.50, median 1.5, standar deviasi 0.707 .

Tabel 1: Distribusi Rata-rata Mual Muntah Sebelum dan Sesudah Pemberian Aromaterapi Jahe pada Kelompok Intervensi

\begin{tabular}{lccc}
\hline \multicolumn{1}{c}{ Mual - Muntah } & Mean & Median & SD \\
\hline Sebelum & 2.73 & 3 & 0.707 \\
\hline Sesudah & 1.13 & 1 & 1.126 \\
\hline
\end{tabular}

Berdasarkan tabel di atas menunjukan bahwa hasil pretest dan posttest mual muntah pasca operasi pada kelompok intervensi didapatkan hasil mean 2.73 , median 3 , standar deviasi 0.707 , nilai minimum 2 dan nilai maksimum 4 . Sedangkan hasil posttest mual muntah pasca operasi pada kelompok intervensi didapatkan hasil mean 1.13, median 1 , standar deviasi 1.126 , nilai minimum 0 dan nilai maksimum 3 .

Tabel 3: Distribusi Analalisia Perbedaan Mual Muntah Sebelum dan Sesudah Perlakuan pada kelompok kontrol dan intervensi

\begin{tabular}{lcccc}
\hline \multirow{2}{*}{ Kelompok } & \multicolumn{4}{c}{ Mual - Muntah } \\
\cline { 2 - 5 } & $\mathrm{n}$ & Mean & SD & $\rho$ value \\
\hline Kontrol & 8 & 0.75 & 0.463 & \multirow{2}{*}{0.003} \\
\hline Intervensi & 8 & 1.63 & 0.707 & \\
\hline
\end{tabular}

Berdasarkan tabel di atas menunjukan perbedaan selisih rata-rata skor mual muntah pada kelompok kontrol 
dan kelompok intervensi adalah 0.88. hasil uji statistik dengan $t$-independent didapatkan nilai $\rho$ value 0.003 , maka $\mathrm{H} 0$ ditolak, sehingga dapat disimpulkan adanya pengaruh aromaterapi jahe terhadap mual muntah pasca operasi

\section{PEMBAHASAN}

Berdasarkan hasil penelitian didapatkan data sebanyak 12 responden (75\%) dari 16 responden dengan jenis kelamin perempuan yang mengalami mual muntah pasca operasi, sehingga dapat disimpulkan bahwa perempuan lebih rentan mengalami mual muntah pasca operasi. Hal ini terjadi dikarenakan oleh pengaruh hormon pada wanita, seperti yang dijelaskan oleh Lenka Doubravska et al. dalam penelitian Sholihah et al. (2014) yaitu tingginya frekuensi jenis kelamin perempuan yang mengalami mual muntah pasca operasi diakibatkan adanya pengaruh hormonal yang berkontribusi dalam sensitivitas terhadap kejadian mual muntah pasca operasi.

Selain jenis kelamin faktor lain yang mempengaruhi risiko mual muntah pasca operasi adalah umur. Angka kejadian mual muntah pasca operasi berdasarkan data hasil penelitian ini didapatkan data responden terbanyak adalah pada kategori umur lansia akhir (56-65 tahun) sebanyak 4 responden $(25 \%)$ dari 16 responden.

Namun hasil penelitian ini bertentangan dengan pendapat Aftab et al. (2008) yang menjelaskan bahwa kejadian mual muntah pasca operasi akan menurun dengan bertambahnya usia. Begitu pula dengan hasil penelitian yang dilakukan oleh Sholihah et al. (2015) tentang Gambaran Angka Kejadian Post Operative Nausea and Vomiting di RSUD Ulin Banjarmasin bahwa umur terbanyak yang mengalami mual muntah pasca operasi adalah umur 40-54 tahun.

Menurut peneliti, hal ini terjadi karena pada usia lansia akhir terjadi penurunan tonus otot sehingga menyebabkan penurunan peristaltik usus pada sistem gastrointestinal.
Gambaran kejadian mual muntah pasca operasi berdasarkan riwayat mual muntah pasca operasi sebelumnya didapatkan data hasil penelitian terdapat 11 responden $(68,75 \%)$ memiliki riwayat mual muntah pasca operasi. Sehingga ini berarti responden yang pernah mengalami mual muntah pasca operasi lebih rentan mengalami mual muntah pasca operasi. Hal ini mungkin dikarenakan CTZ dan vestibular aferen lebih sensitif terhadap rangsangan, baik itu obat maupun rangsangan lain yang terjadi pada responden yang pernah mengalami mual muntah pasca operasi sebelumnya.

Faktor risiko lain yang mempengaruhi kejadian mual muntah pasca operasi adalah status merokok. Hasil penelitian ini menunjukan data terdapat 11 responden (68.75\%) tidak merokok. Sehingga hal ini menunjukkan bahwa responden yang tidak merokok lebih rentan mengalami mual muntah pasca operasi. Hal ini seperti yang disampaikan Anggrahini (2017) dalam penelitiannya bahwa rokok (tembakau) mengandung zat emetogenik sehingga orang yang merokok lebih toleran terhadap zat emetogenik yang terkandung dalam obat-obat anestesi sehingga dapat menurunkan respon mual muntah.

Berdasarkan hasil uji hipotesis dalam penelitian yang menggunakan uji $t-$ Independent dan didapatkan hasil $\rho<0.05$ yaitu $\rho=0.003$. Oleh karena itu maka $\mathrm{H}_{0}$ ditolak dengan kata lain ada pengaruh aromaterapi jahe terhadap mual muntah pasca operasi.

Hal ini sejalan dengan penelitian oleh Hunt, et al. (2013) yang berjudul Aromatherapy as treatment for postoperative nausea: a randomized trial. Didapatkan hasil Perubahan mual tingkat signifikan untuk aromaterapi jahe $(\mathrm{P}=$ $0,002)$ versus garam tapi tidak beralkohol ( $\mathrm{P}<0,76)$. Jumlah obat antiemetik yang diminta responden setelah pemberian aromaterapi itu juga dikurangi secara signifikan dengan jahe versus garam $(\mathrm{P}=$ 0,002 dan $\mathrm{P}<0,001$, masing-masing). Jadi kesimpulannya, hipotesis bahwa aromaterapi akan efektif sebagai 
pengobatan untuk postopertive nausea $(P O N)$. Aromaterapi cukup menjanjikan sebagai perawatan non vasif yang murah untuk postoperative nausea (PON) yang bisa diberikan dan dikendalikan oleh pasien sesuai kebutuhan.

Menurut peneliti, berdasarkan hasil uji analisis bivariat didapatkan perbedaan nilai mean yang hanya berselisih 0.88 antara nilai mean kelompok intervensi yaitu 1.63 dan nilai mean kelompok kontrol yaitu 0.75. Nilai tersebut mengalami selisih yang kecil mungkin karena beberapa karakteristik responden yang dapat mempengaruhi kejadian mual muntah pasca operasi diantaranya umur terbanyak kategori lansia akhir 4 responden $(25 \%)$, jenis kelamin terbanyak perempuan 12 responden $(75 \%)$, riwayat mual muntah 11 responden $(68.75 \%)$, dan status merokok dengan tidak merokok 11 responden $(68.75 \%)$ dan juga karena ada karakteristik responden lainnya yang dapat mempengaruhi mual muntah tetapi tidak terindentifikasi oleh penulis misalnya, kelainan metabolik pada responden.

Terjadinya mual muntah pasca operasi menurut karakteristik responden, hal ini mungkin dikarenakan pada umur lansia akhir terjadi penurunan tonus otot terutama pada peritoneal sehingga dapat menyebabkan distensi abdomen dan menyebabkan penurunan peristaltik usus yang kemudian akan menimbulkan terjadinya rasa mual muntah. Jenis kelamin juga mempengaruhi mual muntah, perempuan lebih rentan mengalami mual muntah pasca operasi yang mungkin disebabkan oleh faktor hormon selanjutnya karakteristik responden dengan riwayat mual muntah pasca operasi lebih banyak dari pada yang tidak memiliki riwayat mual muntah pasca operasi dan responden yang memiliki riwayat mual muntah pasca operasi lebih berpotensial untuk mengalaminya lagi karena CTZ dan vestibular aferen lebih sensitif terhadap rangsangan. Karakteristik responden status merokok dalam penelitian ini responden yang tidak merokok lebih banyak dan kita ketahui rokok (tembakau) mengandung zat emetogenik sehingga orang yang merokok lebih toleran terhadap zat emetogenik yang terkandung dalam obat-obat anestesi sehingga dapat menurunkan respon mual muntah meskipun begitu merokok dapat menimbulkan efek yang sangat berbahaya bagi sistem pernafasan, sistem kardiovaskule serta sistem reproduksi karena mengandung karbonmonoksida, gas oksida, benzene, zat arsenik, dan formalin

Adanya pengaruh aromaterapi jahe terhadap mual muntah pasca operasi, mungkin karena minyak atsiri jahe mengeluarkan aroma khas yang disebabkan zat zingiberol. Kemudian ketika aroma jahe dihirup molekul yang mudah menguap (voltile) dari minyak tersebut akan merangsang memori dan respon emosional. Kemudian merangsang hipotalamus yang berperan sebagai relay dan regulator, memunculkan pesan-pesan yang harus disampaikan ke bagian lain otak serta bagian yang lain. Pesan yang diterima itu kemudian diubah menjadi tindakan yang berupa pelepasan senyawa elektrokimia yang menyebabkan euphoria, relaks, atau sedatif. Aroma jahe juga bekerja menghambat reseptor serotonin dan menimbulkan efek antiemetik pada sistem gastrointestinal dan sistem susunan saraf pusat. Jika dilihat dari hasil penelitian berdasarkan karakteristik responden umur dalam penelitian ini didapatkan umur kategori lansia akhir (56-65 tahun), menurut peneliti hal ini mungkin terjadi karena pada umur tersebut terjadi penurunan tonus otot terutama pada peritoneal sehingga dapat menyebabkan distensi abdomen dan menyebabkan penurunan peristaltik usus yang kemudian akan menimbulkan terjadinya rasa mual muntah. Akan tetapi, dalam penanganan mual muntah pasca operasi di RSUD Dr. H. Abdul Moeloek Provinsi Lampung hanya menggunakan terapi farmakologi dan belum dijadikan terapi non farmakologi khususnya terapi komplementer aromaterapi jahe. 


\section{KESIMPULAN}

Berdasarkan hasil penelitian dapat disimpulkan bahwa telah terjadi penurunan skor mual muntah pasien paska operasi lebih besar pada pemberian aromaterapi jahe daripada pemberian plasebo. Hasil uji $t$-Independent didapatkan hasil $\rho<0.05$ yaitu $\rho=0.003$ berarti ada pengaruh aromaterapi jahe terhadap mual muntah pada pasien pasca operasi dengan anestesi umum.

Berdasarkan kesimpulan tersebut maka disarankan kepada rumah sakit dan perawat untuk dapat menerapkan aromaterapi jahe sebagai alternatif intervensi untuk mngatasi masalah mual muntah pada pasca operasi dengan tetap memperhatikan kondisi individual pasien.

\section{DAFTAR PUSTAKA}

Aftab, S., Khan, A. B., \& Raza, G. (2008). assessment of risk factors of postoperative nausea and vomiting. Journal of the College Physicians and Sergeons Pakistan, 137-141.

Hunt, R., Dienemann, J., Norton, H., Hartley, W., Hudgens, A., Stern, T., \& Divine, G. (2013). Aromatherapy as treatment for postoperative nausea: a randomized trial. Anesthesia \& Analgesia. Anasthesia \& Analgesia, 597-604.

Kozier, B., Erb, G., Berman, A., \& Snyder, S. J. (2010). Buku Ajar Fundamental Keperawatan : Konsep, proses, dan praktik Edisi 7 Volume 2. Jakarta: EGC.

McCracken, G., Houston, P., \& Lefebvre, G. (2008). Guidline for the management of postoperative nausea and vomitting. Journal of obstetrics and gynaecology Canada, 600-607.

Sholihah, A., Marwan, K., \& Husairi, A. (2014). Gambaran angka kejadian Post operative nausea and vomiting (PONV) di RSUD Banjarmasin MeiJuli 2014. 119-129.

Sjamsuhidajat, R., Karnadihardja, W., Prasetyono, T. O., \& Rudiman, R. (2010). Buku Ajar Ilmu Bedah Edisi 3. Jakarta: EGC.

Wijaya, A. A., Fithrah, B. A., Marsaban, A. H., \& Hidayat, J. (2014). Efektivitas pemberian cairan praoperatif ringer laktat 2 $\mathrm{ml} / \mathrm{kgBB} / \mathrm{jam}$ puasa untuk mencegah mual muntah pascaoperasi . Jurnal Anestesi Perioperatif, 200-207. 